\title{
Employment Profile and Program Relevance: Bases for Quality Measures Towards Language Curriculum
}

\author{
Jhordan T. Cuilan \\ Benguet State University-College of Arts and Sciences Province of Benguet, CAR, Philippines \\ j.cuilan@bsu.edu.ph/09396198707 \\ Cynthia T. Lubiton \\ Benguet State University-College of Arts and Sciences Province of Benguet, CAR, Philippines \\ c.lubiton@bsu.edu.ph
}

DOI: http://doi.org/ 10.36892/ijlls.v3i4.773

\begin{tabular}{|c|c|}
\hline $\begin{array}{l}\text { Received: } \\
\text { 29/11/2021 }\end{array}$ & Thic waseang imuled and \\
\hline $\begin{array}{l}\text { Accepted: } \\
\text { 08/12/2021 }\end{array}$ & $\begin{array}{l}\text { competence for enhancements responsive and relevant to the standards of the } \\
\text { new educational landscape and of the employment agencies'growing needs and } \\
\text { demands. Descriptive survey method embedding interview was used to address } \\
\text { the objectives. Employing total enumeration, } 70 \% \text { retrieval rate of the }\end{array}$ \\
\hline $\begin{array}{l}\text { Keywords: } \\
\text { Employment profile, } \\
\text { program relevance, } \\
\text { quality measures, } \\
\text { curriculum review/ } \\
\text { enhancement. }\end{array}$ & $\begin{array}{l}\text { instrument administered was recorded. Statistical and thematic analyses } \\
\text { revealed that the MA-ESL degree, as similarly concluded, is contributory to } \\
\text { the professional advancement of the graduates as supported by the high } \\
\text { employment rating obtained consistent with the graduates' regular status in } \\
\text { professional occupational classifications and business lines. Significantly, the } \\
\text { school-related factors were generally found very relevant- giving premium to } \\
\text { curriculum, goals and objectives, and faculty and instruction. The work- related } \\
\text { values on the other hand were rated highly useful-assessing perseverance and } \\
\text { hard work of utmost importance. Of the general competencies, communication, } \\
\text { knowledge and technical, and research were primarily found useful. } \\
\text { Meanwhile, the feedback derived from the graduates, crosschecked with the } \\
\text { above results, provided quality and timely enhancement measures. It is then } \\
\text { forwarded that the proposed plan highlighting specific measures in the areas of } \\
\text { curriculum and faculty and instruction may be adopted and accorded periodic } \\
\text { evaluation. }\end{array}$ \\
\hline
\end{tabular}

\section{INTRODUCTION}

Higher Education Institutions (HEIs), as accounted, take on the primary role of providing advanced knowledge and skills that fit the qualifications for positions in government, industry and various sectors (Burnett, 2013; Haider, 2008). Higher education develops skills and competencies that equip students for future employment (Ojedokun \& Moahi, 2005). It is then essential that program offerings constantly undergo evaluation primarily of the curriculum to sustain quality and relevance of content in line with the demands of the status quo (Shongwe \& Ocholla, 2011; Zainab, Edzan, \& Rahman, 2004); two of the ways by which institutions have this include engagement in accreditation and conduct of graduate tracer studies.

Cognizant of the challenges posted in today's academic realm, Menez (2014) summed that HEIs indeed should not be limited to merely delivering academic content but also to 
contributing to sustain a competitive economy. Significantly, the same should aim for assisting the graduates land their dream jobs and eventually become successful in their respective fields. Of equal importance, Dotong et. al (2016) added that possession of character and values places one to a higher degree; noting on technical skills next to work attitude.

Institutions utilize and adopt assurance mechanisms evaluating the quality of program offerings and graduates. In essence, Dotong and Laguador (2015); Macatangay (2013); and, Orence and Laguador (2013) accounted that these mechanisms serve the role of assessing the performance of institutions where employability really exists. Contextualized to the Philippine setting, the governing body, Commission on Higher Education (CHED), mandated the facilitation and conduct of Graduate Tracer Studies (GTS). This is to assess the relevance of higher education programs reflected through the employability rate of graduates and further cross-checked with employers' expectations. This is also in line with the mandate of the Accrediting Agency of Chartered Colleges and Universities in the Philippines (AACCUP), Inc. encouraging conduct of tracer studies for purposes of quality assurance.

It is in this line that this study was conducted to evaluate the significance of the concerned program's curriculum given the changing demands, the skills acquired by the graduates relevant to their employment, and the values useful in the graduates' job placement largely serving as bases for the offering department and the university as a whole in improving the program. The findings served as bases for the researchers for enhancements in the curriculum to make it tailored on the new CHED undergraduate curriculum and more responsive to industry needs and expectations for future program enrollees.

Ultimately, the study aimed to trace and establish a profile of the graduates of the degree Master of Arts in English as a Second Language (MA- ESL) under the College of Arts and Sciences- Department of Humanities (CAS- Hum) in one of the state universities in the Cordillera Administrative Region, Philippines. This profile, alongside an assessment of identified factors and competencies, serves as bases in constructing quality measures for curriculum review and enhancement. Conceptually, the study responds to the CHED mandate; whereas, addressing gaps in literature, results practically contribute to the limited GTS evaluating a Graduate Program's curriculum and student performance.

\section{Review of Literature}

\subsection{Relevance of the Curricula: Addressing Issues of Employability}

In the international scene, Ocholla and Shongwe (2011) investigated the employability of the graduates of the Library and Information Science (LIS) degree and the group's perceptions of the curriculum. They found that the graduates were primarily employed in government institutions and were generally satisfied with the knowledge and skills learned at the university. Earlier studies involving LIS graduates as that of Zainab, Edzan, and Rahman (2004) in Malaysia revealed that graduates were satisfied with the courses specifically ICT related modules given the subjects' practical nature. Contrastingly, an immediate need to restructure the LIS curriculum across schools was forwarded by Baruah and Hangsing (2012) necessitating alignment between the courses' contents and the standards of the job market.

Mahood (2012) explained that the LIS curriculum review in Pakistan has rooted from the seemingly non-response of LIS schools to technological advancements consequently affecting the performance of their graduates. It was established that employers expected the graduates to possess competencies appealing to ICT, leadership, and communication skills. In a more recent study, Mugwisi and Hikwa (2015) and Arellano-Tamayo (2019) recommended the involvement of all the stakeholders primarily the employers, graduates, and the offering institution in the process of curriculum review/ enhancement- with distinction to suggested 
offerings. Meanwhile, specifically appealing to curricular revisions, Junaidi (2018) proposed that while the curriculum components may have significantly responded to the technical and knowledge needs of the students, fundamental program objectives still need to be reconsidered.

In the national setting, Garcia and Menez (2008) proposed an enhancement in the graduate program and concluded that a great percentage of the Master in Business Administration (MBA) graduates in their institution accounted for promotion upon completion of their degree; management subjects were similarly found useful in their respective places of work. Menez (2014), in a recent study, further revealed that graduates are gainfully employed holding managerial and professional positions with regular status. The professional subjects, curriculum, and instruction gained from the institution were also found to be relevant to their respective functions.

In line with tourism and engineering- related programs, graduates attained beyond average employment ratings (Aguila, De Castro, Dotong, \& Laguador, 2016; Dimalibot, Diokno, Icalla, Mangubat, \& Villapando, 2014; Laguador \& Dotong, 2013; Macatangay, 2013). This serves true among information technology graduates in spite of the challenges encountered along knowledge and skills and attitudes (Balingbing, 2014). Concorde (2009, as cited in Balingbing, 2014) meanwhile revealed that graduates of technical courses encountered less difficulty in landing a job. As has been customarily observed however, employees have to go through retraining before they are hired on a regular basis in industries- local or national.

\subsection{School- Related Factors and Work- Related Values}

Bojuwoye (2006, cited in Macatangay, 2013) revealed some school-related factors highly rated to indicate stronger effects on students' academic performance. Interestingly, lack of resource materials (for teaching) appeared to be the characteristic that has the greatest effect. It may be deduced that school-related factors, by definition, may jump out of the curriculum to include other areas that shape the school environment. In essence, the study adapted the said factors identified by Macatangay (2013) covering faculty and instruction, curriculum, student services, community extension and linkages, and organization and administration with inclusion of goals and objectives and physical plant and facilities anchored on the areas of evaluation by the AACCUP, Inc.

As to values, Richardson (2010) agreed that the employees' behavior and attitudes make the key ingredients for quality service. In support, Agtay et. al (2013, cited in Dimalibot et. al., 2013) cautioned that reflection of quality performance begins with the self; those who invest on preparation sustaining high energy, who possess elements of extroversion, and who commit to providing services of high quality will find themselves climbing the ladder of success. One of the contributors to having these shaped within an individual is the academic institution. In line with the study, the researchers adopted similar work-related values identified by Laguador and Dotong (2013).

\subsection{General Competencies/Skills}

With regard to competencies and skills, Zaharim et al. (2012) shared that communication, problem solving, teamwork and decision making are the commonly required employability skills needed by graduates in order to deal with real- world problems. Morley and Harvey (2001) similarly identified six generic skills, which include: communication; information technology; application of numbers; working with others; problem solving; and, improving own learning and performance. Meanwhile, Malik (2021) identified performance through effective communication, attitudinal and transferable skills, and self-management skills as 
ingredients to employability. Of critical importance, Mahfoodh and Hashim (2021) underscored skilled communication as essential assessment criterion.

Gines (2014) accounted that very adequate provision of the skills such as communication, knowledge and technical, leadership, human relations, problem solving, research and other competencies specific to the students' areas of specialization through opportunities designed for the development of these is a crucial factor for immediate job acquisition. Likewise, Ramirez, Cruz, and Alcantara (2014) concluded that school- acquired skills and competencies (human relations, communication, entrepreneurial, problem solving, information technology, critical thinking, and other skills) of the graduates greatly helped them in the performance of their jobs. Specifically, Macatangay (2013) earlier found that information technology and communication skills ranked first, followed by problem solving, critical thinking, human relations, and entrepreneurial skills. Communication and IT skills were also found highly relevant by Laguador and Dotong (2013); Dimalibot et. al (2013); and, Aguila et. al (2016). Menez (2014) meanwhile highlighted communication and relations skills.

\subsection{Measures for Curriculum Enhancement}

The rich pool of information derived from the tracer served as important indicators of the current standing of the MA- ESL Program and of other areas needing enhancement.

In light of the above, various recommendations account for the strengthening of the skills and competencies for curricular offerings more relevant to the current work opportunities that could make curricular offerings more relevant to current jobs as reviewing, updating, benchmarking, and establishing linkages among others while ensuring provision of skill/ competency development programs; this is specifically by Estera (2020),; Laguador and Dotong (2013); Macatangay (2013); Ramirez et. al (2014); Menez (2014); Balingbing (2014); and, Mugwisi and Hikwa (2015). Even earlier accounts as that of de Guzman and de Castro (2008) forwarded and generalized the need to develop a more functional employability framework where, to quote, "the diversity of fields of study offered in universities are linked to the diversity of employment."

The proposed action plan by Aguila et.al (2016) focused on the employability and skills development strategies of students through the delivery of instruction- specifically areas as employability, education, and work values. The proposed measures/ activities by Balingbing (2014) on the other hand, which were based largely on the student responses, were intended to enhance the competencies of graduates.

\section{METHODOLOGY}

\subsection{Research Design}

The study utilized the Descriptive Survey Method given the establishment of the graduates' employment profile in general and their evaluation of the MA - ESL Program Curriculum as to relevance of areas specified to their employability and current employment. Interview Method was also employed as a form of validation and data gathering process on the distinct results derived.

\subsection{Respondents of the Study}

Study respondents included the MA- ESL Program graduates from 1997 to 2019. Understanding that the tracer study is being conducted for the first time, total enumeration was 
considered which is emphatic of the retrieval rate of the questionnaires administered. Of the 198 graduates based on records by the Office of the University Registrar, 191 were traced. It is from the latter that the retrieval rate of $70 \%$ (133) was based. Markedly, this is above the expected rate for graduate tracer studies of 30- 60 percent as recommended by Schomburg (2003). The frequency distribution of the graduates by year of completion of the MA- ESL degree is shown in Table 1.

Table 1. Frequency Distribution of Graduates by Year of Completion of the MA- ESL Degree

\begin{tabular}{lcc}
\hline \hline Academic Year & Frequency & Percentage \\
\hline AY 1998- 1999 & 1 & 0.75 \\
AY 2000- 2001 & 1 & 0.75 \\
AY 2001- 2002 & 1 & 0.75 \\
AY 2003- 2004 & 2 & 1.50 \\
AY 2005- 2006 & 4 & 3.01 \\
AY 2006- 2007 & 2 & 1.50 \\
AY 2007- 2008 & 9 & 6.77 \\
AY 2008- 2009 & 5 & 3.76 \\
AY 2009- 2010 & 6 & 4.51 \\
AY 2010- 2011 & 10 & 7.52 \\
AY 2011- 2012 & 7 & 5.26 \\
AY 2012- 2013 & 15 & 11.28 \\
AY 2013- 2014 & 11 & 8.27 \\
AY 2014- 2015 & 18 & 13.53 \\
AY 2015- 2016 & 11 & 8.27 \\
AY 2016- 2017 & 12 & 9.02 \\
AY 2017- 2018 & 8 & 6.02 \\
AY 2018- 2019 & 10 & 7.52 \\
\hline Total & 133 & 100.00 \\
\hline
\end{tabular}

Table 2 on the other hand presents the MA-ESL graduates' relevant profile variables. Notably, a great percentage of the graduates are females and that most are coming from the Cordillera Administrative Region (CAR). With regard to educational attainment, more than eighty percent of the graduates finished BSE- major in English. It is also recognized that nonEnglish major or non-education graduates in general are catered to given their completion of the 12-unit required undergraduate English major subjects. Meanwhile, almost about 40 percent pursued with Doctor of Philosophy degrees. Though the demographics did not account of the nationality of the graduates, three of the 198 are Korean nationals.

Table 2. Demographic Profile of MA-ESL Graduates

\begin{tabular}{|c|c|c|}
\hline Profile Variables & Frequency & Percentage \\
\hline \multicolumn{3}{|l|}{ 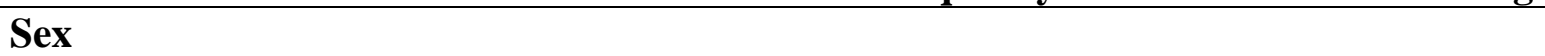 } \\
\hline Female & 113 & 84.96 \\
\hline Male & 20 & 15.04 \\
\hline \multicolumn{3}{|l|}{ Region of Origin } \\
\hline CAR & 117 & 87.97 \\
\hline Region I & 11 & 8.27 \\
\hline Region IV & 2 & 1.50 \\
\hline Region III & 1 & 0.75 \\
\hline Region V & 1 & 0.75 \\
\hline ARMM & 1 & 0.75 \\
\hline
\end{tabular}




\begin{tabular}{lcc}
\hline Baccalaureate Degree & & \\
\hline BSE-English & 110 & 82.71 \\
AB English & 9 & 6.77 \\
AB Communication & 5 & 3.76 \\
BEE- English & 3 & 2.26 \\
BSE- English Literature & 1 & 0.75 \\
BSE- Library Science & 1 & 0.75 \\
BS Nutrition and Dietetics & 1 & 0.75 \\
BS Electrical Engineering & 1 & 0.75 \\
BS Theology & 1 & 0.75 \\
BS Biology & 1 & 0.75 \\
\hline Advanced Studies & & \\
\hline PhD Completed & 20 & 15.04 \\
PhD On-going/ With Units & 18 & 13.53 \\
PhD Dissertation in Progress & 7 & 5.26 \\
MS Information Studies & 1 & 0.75 \\
MA Library and Information Science & 1 & 0.75 \\
No other Advanced Degrees & 86 & 64.66 \\
\hline \hline
\end{tabular}

\subsection{Instrumentation}

Insured of validity by experts, the tracer questionnaire developed by CHED comprised of two parts was adapted; Part I is on the Employment Data covering: a) personal information; b) educational background; c) employment characteristics; d) employment history; e) professional achievement; and, f) transition; and, Part II is on the Evaluation of the Program including: a) satisfaction with the services, learning environment, and facilities; b) adequacy of skills learned; and, c) adequacy and relevance of curricular program with inclusion of workrelated values found useful by the graduates. This however still went through internal piloting for further validation.

\subsection{Data Gathering}

Before the actual gathering of data, personal messages were sent to the graduates. This practically aimed to initially communicate the researchers' intent to elicit relevant data needed for the study. In any way, it also served as a confirmation of their profile given the scope of the survey tracing graduates from various years. Upon conversion of the questionnaire in Google Forms, similar message encouraging graduate participation served as the cover. Strengthening ethical considerations, they were informed of the study's nature and intent, benefits, and risks.

Distribution of questionnaires was done primarily through online platforms as messenger, Facebook, and e-mail. The link of the questionnaire translated in customized Google Forms which assisted the researchers in gathering the data was individually sent to the graduates; series of follow up was also done. Similar platforms were utilized to carry out the follow up interviews guided by the questions derived from distinct results. Shedding light to the process, given that the study was undertaken at the onset of the pandemic, direct calls through messenger and Google Meet were facilitated. It is to note that these were carried based on the participants' most convenient time. The researchers also managed to communicate the questions through direct messaging especially to those who are, during the gathering, based abroad.

\subsection{Data Analysis}


The following statistical tools were utilized in interpreting the data obtained through the questionnaire: frequency, weighted mean, percentage, and rank. To address the relevance of school- related factors and usefulness of the work- related values, a 4-point rating scale was utilized. To arrive at a verbal description of each item, the numerical guide considered is as follows: 3.50- 4:00 (Very Relevant/ Highly Useful); 2.50- 3.49 (Relevant/ Useful); 1.50- 2.49 (Slightly Relevant/ Slightly Useful); and, 1:00- 1.49 (Not Relevant/ Not Useful). As to the general competencies found useful, frequency count guided the researchers.

Basic qualitative analysis meanwhile justified the treatment of the verbal responses. Following the process, the interview recordings were first transcribed verbatim. In the process, coding was done to sustain consistency between the participants and their verbalizations. Having identified the significant responses from the pool of data, commonality in words, phrases, and expressions shaping the emerging terminology guided the researchers in clustering the ideas. These clusters then formed the categories which in turn were linked with the quantitative results.

\section{RESULTS AND DISCUSSION}

\subsection{Employment Profile of the MA- ESL Graduates}

Various factors were considered in describing the employment profile of the graduates. The following tables present their frequency distribution taken in general through variables.

Table 1. Distribution of MA- ESL Graduates in Terms of Employment/ Non-employment Classifications

\begin{tabular}{lcc}
\hline Classifications & Frequency & Percentage \\
\hline Presently Employed & 129 & 96.99 \\
Not Presently Employed & 4 & 3.01 \\
Never Been Employed & 0 & 0.00 \\
\hline \hline
\end{tabular}

The table accounts for the MA-ESL graduates' general employment/ non-employment classifications. As gleaned from the table, the group obtained an overall employment rating of 96.99 percent (129 of 133). This technically implies of high employability or far beyond average employment rating among the graduates which, in consideration of the context however, is contradictory to the results derived by Aguila, De Castro, Dotong, and Laguador (2016); Dimalibot, Diokno, Icalla, Mangubat, and Villapando (2014); Laguador and Dotong (2013); and Macatangay (2013). On the other hand, 3.01 percent accounting to four (4) individuals traced are currently unemployed. Investigating on the reasons for unemployment, responses primarily highlight family concerns; this allowed two of the graduates to decide not to find a job momentarily. Dotong et. al (2016) similarly documented on family concerns as the primary reason for unemployment in the context of engineering graduates.

Table 2. Distribution of MA- ESL Graduates in Terms of Present Employment Status and Place of Work

\begin{tabular}{lcc}
\hline \hline Present Employment Status & Frequency & Percentage \\
\hline Regular or Permanent & 108 & 83.72 \\
Contractual & 11 & 8.53 \\
Contract of Service & 3 & 2.33 \\
Casual & 3 & 2.33 \\
Temporary & 1 & 0.78 \\
Self-employed & 1 & 0.78 \\
Others: Probationary & 2 & 1.55 \\
\hline Total & 129 & 100.00 \\
\hline
\end{tabular}




\begin{tabular}{lcc}
\hline Place of Work & & \\
\hline Local & 114 & 88.37 \\
Abroad & 15 & 11.63 \\
\hline Total & 129 & 100.00 \\
\hline \hline
\end{tabular}

With reference to the 129 currently employed graduates traced, more than eighty percent or 108 are of regular or permanent status; whereas, others are on contractual (11), contract of service (3), casual (3), temporary (1), self-employed (1), and probationary (2) employment. As to place of work, majority or nearly ninety percent (114 of 129) are locally employed. Among their common affiliations include academic institutions, government offices, and private companies. Beyond evident data however on local institutions as primary locale is an evidence of employment in the international setting. This applies to roughly twelve percent (15 of 129) of the employees.

Table 3. Distribution of MA- ESL Graduates in Terms of Present Occupation based on the Philippine Standard Occupational Classification (PSOC) and Major Line of Business

\begin{tabular}{lcc}
\hline \hline Occupational Classification & Frequency & Percentage \\
\hline Managers & 3 & 2.33 \\
Professionals & 117 & 90.70 \\
Clerical Support Workers & 4 & 3.10 \\
Technicians and Associate Professionals & 1 & 0.78 \\
Service Support Workers & 2 & 1.55 \\
Armed Forces Occupations & 1 & 0.78 \\
Craft and Related Trades Workers & 1 & 0.78 \\
\hline Total & 129 & 100.00 \\
\hline Major Line of Company Business & Frequency & Percentage \\
\hline Mining and Quarrying & 1 & 0.78 \\
Public Administration and Defense & 1 & 0.78 \\
Construction & 1 & 0.78 \\
Wholesale and Retail Trade & 2 & 1.55 \\
Education & 121 & 93.80 \\
Health and Social Work & 1 & 0.78 \\
Others: Business Processing Outsource & 1 & 0.78 \\
Peace and Order & 1 & 0.78 \\
\hline Total & 129 & 100.00 \\
\hline \hline
\end{tabular}

In line with the graduates' employment status is their distribution based on the Philippine Standard Occupational Classification (PSOC) and major line of company business employed in. As verified, ninety percent or 117 of the graduates are classified as professionalsin this context, largely focused on the teaching profession. Specific of their work areas and descriptions of activities shared, four (4) are clerical support workers; three (3) are managers; two (2) are service support workers; and, one (1) for the following classifications respectively: technicians and associate professionals, armed forces occupations, and craft and related trades workers.

Anchored on the classifications, it follows that a great percentage $(93.80 \%$ or 121 of 129 ) of the graduates are in the major business line of education. Others are affiliated with business companies in line with wholesale and retail trade (2), mining and quarrying (1), public administration and defense (1), construction (1), health and social work (1), business processing outsource (1), and peace and order (1). 
Table 4. Distribution of MA- ESL Graduates in Terms of Current Employment as First after Completing MA Degree

\begin{tabular}{lcc}
\hline \hline Employment as First Job after MA & Frequency & Percentage \\
\hline Yes & 41 & 31.78 \\
No & 88 & 68.22 \\
\hline Total & 129 & \\
\hline \hline
\end{tabular}

The MA-ESL graduates were further distributed based on whether or not their current employment is their first job after completing the degree. In this essence, the discussion included only those who are currently employed. As quantified in the table, of the 129 graduates, $31.78 \%$ or 41 accounted that their current employment is their first job after completing the degree; whereas, $68.22 \% 88$ shared on having a different job before their current employment contextually after finishing MA. With this, Tables 5 and 6 expound on the reasons for accepting the job and staying in the same respectively among the 41 graduates. Table 7 on the other hand addresses the reasons among the 88 graduates for changing jobs towards their current position/ affiliation. It also provides details on an average length of stay in their previous jobs.

Table 5. Distribution of MA- ESL Graduates in Terms of Reasons for Accepting the Job

\begin{tabular}{lccc}
\hline \hline Reasons & Frequency & Percentage & Rank \\
\hline Salaries and Benefits & 28 & 68.29 & 2 \\
Career Challenge & 30 & 73.17 & 1 \\
Related to Special Skill & 24 & 58.54 & 3 \\
Related to Course or Plan of Study & 0 & 0.00 & 6 \\
Peer Influence & 0 & 0.00 & 6 \\
Proximity to Residence & 13 & 31.71 & 4 \\
Family Influence & 0 & 0.00 & 6 \\
\hline \hline
\end{tabular}

Specifically, what primarily made the 41 graduates accept their current job after completing their MA degree as gleaned from the table is the career challenge this brought. In any way, this is consistent with their top reason for pursuing MA on career/ professional advancement as verified. The challenge the profession holds allowed for advancement in their careers. The salaries and benefits the job offered ranked second. Though there are some who have already been employed in the same job before and after having the degree completed, they reason anyway that such is related to their special skills.

Table 6. Distribution of MA- ESL Graduates in Terms of Reasons for Staying in the Job

\begin{tabular}{lccc}
\hline Reasons & Frequency & Percentage & Rank \\
\hline Salaries and Benefits & 30 & 73.17 & 1.5 \\
Career Challenge & 30 & 73.17 & 1.5 \\
Related to Special Skill & 16 & 39.02 & 4 \\
Related to Course or Plan of Study & 26 & 63.41 & 3 \\
Peer Influence & 1 & 2.44 & 7 \\
Proximity to Residence & 14 & 34.15 & 5 \\
Family Influence & 2 & 4.88 & 6 \\
\hline \hline
\end{tabular}

Interestingly, the primary reasons that made the graduates stay in the job were the same factors that guided them in accepting this in the first place. Reasons as career challenge and salaries and benefits shared the top rank of 1.5. Even at the attainment of the degree, the graduates continue to recognize the challenge posted by the profession that shapes their career. 
They also continue to invest on the thought that their current employment is related to their special skill and course or plan of study.

Table 7. Distribution of MA- ESL Graduates in Terms of Reasons for Changing Job and Average Length of Stay in First Job

\begin{tabular}{|c|c|c|c|}
\hline Reasons & Frequency & Percentage & Rank \\
\hline Salaries and Benefits & 77 & 87.50 & 1 \\
\hline Career Challenge & 63 & 71.59 & 2 \\
\hline Related to Special Skill & 42 & 47.73 & 3 \\
\hline Related to Course or Plan of Study & 41 & 46.59 & 4 \\
\hline Proximity to Residence & 31 & 35.23 & 5 \\
\hline Peer Influence & - & - & - \\
\hline Family Influence & 6 & 6.82 & 6 \\
\hline Others: Personal and Professional Development & 1 & 1.14 & 10 \\
\hline Contractual Status & 1 & 1.14 & 10 \\
\hline Personal Conviction & 1 & 1.14 & 10 \\
\hline End of Contract & 1 & 1.14 & 10 \\
\hline Advanced Studies & 1 & 1.14 & 10 \\
\hline Stability & 3 & 3.41 & 7 \\
\hline \multicolumn{4}{|l|}{ Average Length of Stay in Previous Job } \\
\hline $1-6$ months & 11 & 12.50 & \\
\hline 7-11 months & 8 & 9.09 & \\
\hline 1 year to less than 2 years & 17 & 19.32 & \\
\hline 2 years to less than 3 years & 17 & 19.32 & \\
\hline 3 years to less than 4 years & 22 & 25.00 & \\
\hline Others: & & 0.00 & \\
\hline 4 years & 2 & 2.27 & \\
\hline 5 years & 3 & 3.41 & \\
\hline 6 years & 4 & 4.55 & \\
\hline 7 years & 1 & 1.14 & \\
\hline 9 years & 1 & 1.14 & \\
\hline 13 years & 1 & 1.14 & \\
\hline 15 years & 1 & 1.14 & \\
\hline
\end{tabular}

With reference to those with previous jobs before their current employment after MA, their primary reasons for changing job similarly include concerns on salaries and benefits and career challenge. Sharing almost similar mean values are reasons pertaining to special skill and course or plan of study. Reviewing the other reasons indicated, others changed job for personal and professional development and advanced studies and due to personal conviction and being on contractual status. Verified by their reasons for pursuing MA in the first place, they aimed for positions that may satisfy their concept of stability, reflected in prospect for compensation and work challenge, which they believe may be attained partly through the completion of the degree. On average, the graduates stayed in their first job after MA before their current employment for one (1) to three (3) years.

Table 8. Frequency Distribution of MA- ESL Graduates in Terms of Means of Finding and Length of Time before Landing their Current Job

\begin{tabular}{lccc}
\hline \hline Means of Finding Job & Frequency & Percentage & Rank \\
\hline Response to an advertisement & 36 & 27.91 & 2 \\
Arranged by school's job placement officer & 3 & 2.33 & 5.5 \\
Recommended by someone & 44 & 34.11 & 1
\end{tabular}




\begin{tabular}{lccc} 
Information from friends & 16 & 12.40 & 4 \\
As walk-in applicant & 27 & 20.93 & 3 \\
Job Fair or Public Employment Service Office & 3 & 2.33 & 5.5 \\
\hline Length of Time before Finding Job & & & 1 \\
\hline Less than a month & 80 & 62.02 & 2 \\
1-6 months & 34 & 26.36 & 4 \\
7-11 months & 3 & 2.33 & 3 \\
1 year to less than 2 years & 7 & 5.43 & 5.5 \\
2 years to less than 3 years & 2 & 1.55 & 5.5 \\
3 years to less than 4 years & 2 & 1.55 & 7 \\
Others: 5 years & 1 & 0.78 & \\
\hline
\end{tabular}

As to means of finding their current job, table 8 accounts that most (33.11\% or 44) MAESL graduates were recommended for such prospect of employment. Almost 30 percent or 36 responded to an advertisement whereas 20 percent or 27 were walk-in applicants. Recommendations for a job equate to satisfying if not exceeding the qualifications for the position; though this may not hold applicable for everyone, having an edge through educational qualifications is one evident factor.

Also accounted is the period or length of time spent in finding their first job. Notably, more than 60 percent or 80 landed in the job in a month or less. Nearly thirty (30) percent or 34 on the other hand landed in the job within 1 to 6 months. This further affirms the MA-ESL graduates' prospect for employability with the degree serving as one of the contributory factors.

More than identifying the general employment status of the graduates as earlier discussed, cross checking with their place of work specifically gave premium as to where those on non-permanent status are based. Generally, it is to note that most of the non-permanent graduates are affiliated with private institutions and companies based both locally and abroad. Online consultations verified the fast pace of turn-over in terms of position in private schools offering basic education and in ESL industries. For the previous, as commonly accounted, the private schools almost serve as grounds for graduates to gain experience before aiming for permanency in a public institution. For the latter, with Baguio City within the proximity serving as haven to most ESL schools in the country, hiring becomes dependent on the number of students catered to for every season. In light of the casual employees in a public higher education institution, while MA degree serves as a basic requirement for an item, organizations also are on top of considering vacant plantilla or permanent items/positions to be filled. Meanwhile, among those based abroad, one shared that contextually, the country's Ministry of Education (MoE) or Higher Education Council (HEC) does not provide for permanent positions among foreign teachers although contracts may be extended until retirement or until desired consistent with the working VISA and Labor Laws. Another shared however on a possibility of permanency in a specific country given the required trainings one has to undergo.

Table 9. Frequency Distribution of MA- ESL Graduates in Terms of Job Level Position before and after MA

\begin{tabular}{lcc}
\hline \hline Job Level Position & Before MA & After MA \\
\hline Rank or Clerical & 17 & 4 \\
Managerial or Executive & 1 & 3 \\
Professional, Technical, or Supervisory & 109 & 111 \\
Others: Professional, Technical, or & & \\
Supervisory and Managerial/ Executive & 2 & 10 \\
No response & & 1 \\
\hline
\end{tabular}




\begin{tabular}{lll}
\hline Total & 129 & 129 \\
\hline
\end{tabular}

Finally, Table 9 illustrates a general view of the respondents' distribution in the following job level positions before taking and after completing the MA-ESL Degree: Professional, Technical or Supervisory- 109 increased to 111; Rank or Clerical- 17 reduced to 4; Managerial or Executive- 1 to 3; and, Professional Positions with Managerial/ Executive Functions- 2 to 10 . Most notably, graduates who used to be in the rank and clerical positions applied and qualified for professional, technical, and supervisory classified jobs; others who may be in the current job levels were also given managerial and executive functions. Meanwhile, the non-response could be traced to the graduate currently affiliated with a construction company abroad whose job is not directly relevant to the degree completed.

\subsection{Relevance of School- related Factors and Usefulness of Work- related Values}

Table 10. Relevance of School- related Factors to the Job Placement of MA- ESL Graduates

\begin{tabular}{|c|c|c|c|c|c|c|c|c|c|}
\hline \multirow{2}{*}{ School- related Factors } & \multicolumn{2}{|c|}{ 1998-2004 } & \multicolumn{2}{|c|}{$2005-2013$} & \multicolumn{2}{|c|}{ 2014-2019 } & \multirow{2}{*}{$\begin{array}{c}\text { Overall } \\
\text { Mean }\end{array}$} & \multirow{2}{*}{ DE } & \multirow{2}{*}{ Rank } \\
\hline & WM & DE & WM & DE & WM & DE & & & \\
\hline Goals and Objectives & 4.00 & VR & 3.54 & VR & 3.57 & VR & 3.70 & VR & 2 \\
\hline Faculty and Instruction & 3.67 & VR & 3.54 & VR & 3.61 & VR & 3.61 & VR & 3 \\
\hline Curriculum & 4.00 & VR & 3.63 & VR & 3.69 & VR & 3.77 & VR & 1 \\
\hline Student Services & 3.33 & $\mathrm{R}$ & 3.32 & $\mathrm{R}$ & 3.43 & $\mathrm{R}$ & 3.36 & $\mathrm{R}$ & 6 \\
\hline Community Extn./ Linkages & 3.33 & $\mathrm{R}$ & 3.16 & $\mathrm{R}$ & 3.37 & $\mathrm{R}$ & 3.29 & $\mathrm{R}$ & 7 \\
\hline Physical Plant/ Facilities & 3.67 & VR & 3.21 & $\mathrm{R}$ & 3.27 & $\mathrm{R}$ & 3.38 & $\mathrm{R}$ & 5 \\
\hline Organization/ Administration & 3.67 & VR & 3.32 & $\mathrm{R}$ & 3.44 & $\mathrm{R}$ & 3.48 & $\mathrm{R}$ & 4 \\
\hline Overall & 3.67 & VR & 3.39 & $\mathbf{R}$ & 3.48 & $\mathbf{R}$ & 3.51 & VR & \\
\hline
\end{tabular}

Given the enhancements in the MA-ESL curriculum which underscore having the graduates experience the program differently, only in this section, responses were categorized in three clustered batches reflecting the original program contents and two enhancements respectively: 1998- 2004; 2005- 2013; and, 2014- 2019.

Referring to the salient values, batch 1998- 2004 graduates primarily rated goals, objectives, and curriculum to be the top two very relevant factors to their job placement with similar mean ratings of 4.00. Very relevant factors among the 2005- 2013 graduates on the other hand include curriculum and goals and objectives and faculty and instruction with 6.63 and shared 3.54 mean values respectively. Meanwhile, graduates of batch 2014- 2019 found curriculum, faculty and instruction, and goals and objectives as very relevant factors with mean distributions of $3.69,3.61$, and 3.57.

Common among these top factors which in fact obtained the highest values for every group is the curriculum obtaining an overall mean of 3.77. Other factors found most relevant include goals and objectives (3.70) and faculty and instruction (3.61). Based on similar studies, the items were among the top list revealed by Dimalibot et. al (2013), Macatangay (2013), and Menez (2014).

Table 11. Usefulness of Work-related Values to the Job Placement of MA-ESL Graduates

\begin{tabular}{lccc} 
Values & $\begin{array}{c}\text { Weighted } \\
\text { Mean }\end{array}$ & $\begin{array}{c}\text { Descriptive } \\
\text { Equivalent }\end{array}$ & Rank \\
\hline Fairness and justice & 3.69 & HU & 8.5 \\
Courage & 3.68 & HU & 10.5 \\
Creativity and innovativeness & 3.72 & HU & 6
\end{tabular}




\begin{tabular}{lccc} 
Supportiveness & 3.68 & HU & 10.5 \\
Punctuality & 3.70 & HU & 7 \\
Perseverance and hard work & 3.79 & HU & 1 \\
Love for God & 3.73 & HU & 4.5 \\
Unity & 3.66 & HU & 12.5 \\
Obedience to superior & 3.64 & HU & 14 \\
Professional integrity & 3.78 & HU & 2.5 \\
Love for co-workers and others & 3.62 & HU & 15 \\
Leadership & 3.69 & HU & 8.5 \\
Honesty and love for truth & 3.78 & HU & 2.5 \\
Efficiency & 3.73 & HU & 4.5 \\
Tolerance & 3.66 & HU & 12.5 \\
Nationalism & 3.49 & U & 16 \\
\hline Overall Mean & $\mathbf{3 . 6 9}$ & Highly Useful & \\
\hline
\end{tabular}

As to the work- related values identified, which are shared across differences in curriculum, those found highly useful in the graduates' job placement include: perseverance and hard work (3.79); professional integrity and honesty and love for truth (3.78); efficiency and love for God (3.73); creativity and innovativeness (3.72); punctuality (3.70); fairness and justice and leadership (3.69); courage and supportiveness (3.68); tolerance and unity (3.66); obedience to superior (3.64); and, love for co-workers and others (3.62).

Of the values found highly useful, perseverance and hard work topped the list. As accounted, "perseverance is being able to bear several complications or difficulties calmly without complaint; it is commitment, endurance, patience and hard work." To note that employed graduates now are getting involved in an environment which needs hard working professionals who are committed to serve whatever policy or condition might employers have (Laguador \& Dotong, 2013).

4.3.General Competencies MA-ESL Graduates Found Useful Table 12. General Competencies MA-ESL Graduates Found Useful in their Employment

\begin{tabular}{|c|c|c|c|c|c|c|c|c|}
\hline \multirow{2}{*}{ General Competencies } & \multicolumn{2}{|c|}{ 1998-2004 } & \multicolumn{2}{|c|}{$2005-2013$} & \multicolumn{2}{|c|}{ 2014-2019 } & \multirow{2}{*}{$\begin{array}{c}\text { Overall } \\
\%\end{array}$} & \multirow{2}{*}{ Rank } \\
\hline & $\%$ & Rank & $\%$ & Rank & $\%$ & Rank & & \\
\hline Knowledge/ Technical Skills & 100.00 & 2.5 & 77.19 & 2 & 71.43 & 2.5 & 82.87 & 2 \\
\hline Communication Skills & 100.00 & 2.5 & 91.23 & 1 & 88.57 & 1 & 93.27 & 1 \\
\hline Leadership Skills & 33.33 & 6.5 & 33.33 & 6 & 38.57 & 6 & 35.08 & 7 \\
\hline Research Skills & 100.00 & 2.5 & 64.91 & 4 & 71.43 & 2.5 & 78.78 & 3 \\
\hline Human Relations Skills & 33.33 & 6.5 & 56.14 & 5 & 55.71 & 5 & 48.40 & 6 \\
\hline Problem- solving Skills & 100.00 & 2.5 & 28.07 & 7 & 35.71 & 7 & 54.59 & 5 \\
\hline Entrepreneurial Skills & 0.00 & 8.5 & 1.75 & 9 & 5.71 & 9 & 2.49 & 9 \\
\hline IT Skills & 0.00 & 8.5 & 17.54 & 8 & 24.29 & 8 & 13.94 & 8 \\
\hline Critical Thinking Skills & 66.67 & 5 & 70.18 & 3 & 68.57 & 4 & 68.47 & 4 \\
\hline
\end{tabular}

Of the general skills identified, batch 1998- 2004 graduates identified knowledge and technical, communication, research, and problem- solving skills similarly ranking 2.5 to have been useful in their employment endeavors. Communication, knowledge and technical, critical thinking, and research skills on the other hand were highly used by the 2005- 2013 graduates ranking first through fourth respectively. Finally, although of varied ranking, the latter skills were also invested on by the 2014- 2019 graduates. 
Generally, the groups found communication, knowledge and technical, research, and critical thinking skills most useful. Given today's highly competitive market place, graduates need to invest on creating a profile of their own towards landing a job; this is what employability skills practically emphasize (Yusoff, Omar, Zaidi, Mohamed, \& Muhamad, 2012). Contextualized to communication skills, Al-Tamimi and Shuib (2010) noted that priority should be given to speaking skills with this being notably evident among graduates seeking employment. Skills such as communication, knowledge and technical, critical thinking, and research are rather sought after among graduate applicants. As earlier accounted, communication and IT skills were also found highly relevant by Laguador and Dotong (2013); Dimalibot et. al (2013); and, Aguila et. al (2016). Menez (2014) meanwhile highlighted communication and relations skills.

Verifying through a follow up survey as to which of the competencies the graduates actually improved much on through the curriculum, responses mostly accounted to research (41.38\%), knowledge and technical (34.48\%), and communication (10.34\%) skills. It is to note that the scheme of instruction being research-based does not only invest on having students engage in research as course requirement but also on developing reports and course contents from research results.

\subsection{Proposed Plan and Specific Measures}

The proposed action plan highlights specific measures primarily concerning the areas of curriculum and faculty and instruction; it is through these that goals and objectives are restated addressing the demands of the workplace while research is further integrated in the delivery of content. This plan is towards enhancing the competencies of MA-ESL prospects in significant areas reflective of the graduates' experiences and observations summarized through their responses qualitatively analyzed. As communicated, this also aimed to strengthen the relationship of the program- offering department and the university in general with the alumni for curriculum enhancement and for future endeavors fit for them to be engaged in.

Table 13. Proposed Plan and Measures for MA-ESL Curriculum Review and Enhancement and Faculty and Instruction Development

\begin{tabular}{|c|c|}
\hline Key Areas & Proposed Measures \\
\hline Curriculum & \\
\hline$>\begin{array}{l}\text { Review and } \\
\text { Enhancement }\end{array}$ & $\begin{array}{l}\text { Review/ enhancement of curricular offerings based on the new } \\
\text { undergraduate PSG integrating concepts on the } 21^{\text {st }} \text { century } \\
\text { learning skills and sustainable development goals; aim is to have } \\
\text { the system and practices at par with international TESOL or MA } \\
\text { TESOL. } \\
\text { Curricular inclusion of ICT tools in teaching English designed for } \\
\text { development of skills in ICT applications for proofreading, } \\
\text { grammar correcting, or use of MS office in general noting that } \\
\text { these skills would be necessary in the job performance in line with } \\
\text { academic writing. } \\
\text { Transition of subjects towards grammar for mastery of written } \\
\text { communication skills; phonics and phonology; rhetoric; and, } \\
\text { semantics considering the context of non-English speaking } \\
\text { nationalities and areas of employment as advertisement, call center } \\
\text { and marketing companies among others. }\end{array}$ \\
\hline
\end{tabular}




\begin{tabular}{|c|c|c|}
\hline & $>$ & $\begin{array}{l}\text { Designing of opportunities for research and community extension } \\
\text { and linkages as part of the curriculum where students may engage } \\
\text { in. }\end{array}$ \\
\hline \multicolumn{3}{|c|}{ Faculty and Instruction } \\
\hline $\begin{array}{l}\text { Faculty } \\
\text { Development } \\
\text { Training }\end{array}$ & $>$ & $\begin{array}{l}\text { Faculty training on ICT and social media- based platforms of } \\
\text { learning towards professionalized online English instruction. }\end{array}$ \\
\hline$>$ Benchmarking & $>$ & $\begin{array}{l}\text { Conduct of formal benchmarking locally and abroad enriching } \\
\text { perspective of teachers on different systems and practices towards } \\
\text { an international set-up. }\end{array}$ \\
\hline & $>$ & $\begin{array}{l}\text { Provision/ Designing of more avenues for application- based tasks } \\
\text { anchored on the theories/ methods/ approaches delineated in the } \\
\text { course curriculum. }\end{array}$ \\
\hline $\begin{array}{l}\text { Review and } \\
\text { Enhancement }\end{array}$ & $>$ & $\begin{array}{l}\text { Sustaining focus on student-organized culminating events as } \\
\text { seminars and research immersions/presentations guiding and }\end{array}$ \\
\hline $\begin{array}{l}\text { of Course } \\
\text { Syllabi as to }\end{array}$ & & exposing students to specific interests in the field like research. \\
\hline $\begin{array}{l}\text { Activities/ } \\
\text { Strategies and } \\
\text { Mode of } \\
\text { Content } \\
\text { Delivery }\end{array}$ & $>$ & $\begin{array}{l}\text { Inclusion of immersion or community engagement and virtual } \\
\text { simulation for actual dealing with ESL learners as part of } \\
\text { transitioning to the new normal. }\end{array}$ \\
\hline
\end{tabular}

\section{CONCLUSIONS, RECOMMENDATIONS, AND LIMITATIONS}

Given the above results, it is concluded that the MA- ESL degree continues to meet and address the changing needs and demands of the employing organizations and the society. This is supported by the high employment rating of its graduates at $96.99 \%$ (129 of 133) specified on great percentage through $83.72 \%$ with regular status (108 of 129) mostly holding professional positions.

Significantly, the school- related factors were generally found very relevant (3.51). The graduates gave premium on the areas of curriculum; goals and objectives; and, faculty and instruction. The work- related values on the other hand were rated highly useful (3.69) highlighting perseverance and hard work and professional integrity and honesty and love for truth as top among these. Of the general skills embedded, communication, knowledge and technical, research, and critical thinking skills were found useful. Verifying the skills they have improved on the most through the curriculum, research and knowledge and technical skills were underscored. Certainly, these serve as one of the major factors for the graduates' immediate acquisition of their job. Meanwhile, the feedback derived from the graduates consistent with reviews from existing literatures provided significant measures with respect to the key areas of curriculum and faculty and instruction.

It is then recommended that the conduct of tracer studies by curriculum enhancement or by specified period of 4 years may be institutionalized for quality assurance and consistent evaluation of the graduates' employment characteristics. The proposed plan highlighting specific measures for enhancements in the specified curriculum areas may also be adopted and accorded periodic evaluation. This is to insure enhanced competencies of the graduates that continually meet the changing needs and demands of employing agencies/ companies while attracting prospect foreign enrollees. Finally, a follow- up study on this tracer exploring further 
the qualitative phase of the results may be conducted while similarly accounting for the perspective of employers on the graduates' performance.

\section{Acknowledgments}

The authors are deeply grateful to the graduates who patiently and willingly responded to the graduate tracer instrument administered for accommodating the request and for expressing their thoughts during the follow up consultations facilitated. Likewise, the authors thank Benguet State University for such an opportunity for learning.

\section{References}

Aguila, G. M., De Castro, E. L., Dotong, C. I., \& Laguador, J. M. (2016). Employability of computer engineering graduates from 2013 to 2015 in one private higher education institution in the Philippines. Asia Pacific Journal of Education, Arts and Sciences, 3(3), 48-54. http://oaji.net/articles/2016/1710-1475121628.pdf

Al-Tamimi, A. S., \& Shuib, M. (2010). Investigating the English language needs of petroleum engineering students at Hadhramout University of Science and Technology. The Asian ESP Journal, 6(1), 1-30.

Arellano-Tamayo, R. (2019). College English proficiency of freshmen: Basis for language curriculum enhancement. Senior Editor: Paul Robertson, 276.

Balingbing, A. B. (2014). Tracer study of BS in information technology (BSIT) graduates of camarines sur polytechnic colleges, nabua, camarines sur from 2004 to 2010. Asia Pacific Journal of Multidisciplinary Research,2(4). http://www.apjmr.com/wpcontent/uploads/2014/08/APJMR-2014-2-098.pdf

Baruah, B. G., \& Hangsing, P. (2013). Relevance of the rising job market for LIS professionals versus competencies needed with reference to Indian context. Trends in Information Management http://journaldatabase.info/articles/relevance_rising_job_market_for_lis.html

Burnett, P. (2013). Challenges and Problems of Library and Information Science Education in Selected African Countries. http://library.ifla.org/175/1/199-burnett-en.pdf

De Guzman, A. B., \& de Castro, B. V. (2008). Employment and Employability Profile of a Select Group of Filipino College Graduates. Korean Educational Development Institute (KEDI) Journal of Educational Policy, 5:1, 63- 81. https://search.proquest.com/openview/632c10dd40b35bc9344b9d4f05561342/1?pqorigsite $=$ gscholar \&cbl $=946348$

Dimalibot, G. A., Diokno, J. D., Icalla, M. F., Mangubat, M. R. C., \& Villapando, L. C. (2014). Employment status of the Tourism Graduates of batch 2013 in Lyceum of the Philippines University-Batangas. Journal of Tourism and Hospitality Research, 11(1), 46-56. $\quad$ http://research.lpubatangas.edu.ph/wp-content/uploads/2014/08/JTHREmployment-Status.pdf

Dotong, C. I., Chavez, N. H., Camello, N. C., De Castro, E. L., Prenda, M. T. B., \& Laguador, J. M. (2016). Tracer Study of Engineering Graduates of One Higher Education Institution In The Philippines For Academic Year 2009-2012. European Journal of 
Engineering and Technology Vol, 4(4), 26-39. https://research.lpubatangas.edu.ph/wpcontent/uploads/2016/07/EJET-Tracer-Study-of-Engineering-Graduates.pdf

Dotong, C. I., \& Laguador, J. M. (2015). Philippine quality assurance mechanisms in higher education towards internationalization. Studies in Social sciences and Humanities, 3(3), 156-167. $\quad$ https://research.lpubatangas.edu.ph/wpcontent/uploads/2015/12/SSSH-Philippine-Quality-Assurance-Mechanisms-inHigher-Education.pdf

Estrera, E. B. (2020). A Perception-Based Curricular Review on the K to 12 HUMSS Strand Curriculum. IAFOR Journal of Education, 8(4), 25-44. http://iafor.org/archives/journals/iafor-journal-of-education/10.22492.ije.8.4.02.pdf

Gines, A. C. (2014). Tracer study of PNU graduates. American International Journal of Contemporary Research, 4(3), 81-98. http://www.aijcrnet.com/journals/Vol_4_No_3_March_2014/10.pdf

Haider, S. Z. (2008). Challenges in Higher Education: Special Reference to Pakistan and South Asian Developing Countries. Nonpartisan Education Review, Essays, 4(2), 1-12.

Junaidi, A. (2018). Evaluating the Relevance Status of Linguistics-Based Courses in English Teacher Education Program in Indonesia: A Case Study at the University of Mataram. Senior Editor: Paul Robertson, 71.

Laguador, J. M., \& Dotong, C. I. (2013). Tracer study of BS computer engineering graduates of Lyceum of the Philippines University. International Journal of Management, IT and Engineering, 3(8), $\quad 387 . \quad$ https://research.lpubatangas.edu.ph/wpcontent/uploads/2014/04/IJMIE-Tracer-Study-of-BS-Computer-Engineering.pdf

Loretto, P. (2012). The Top Ten Work Values Employers Look For, More Personal Values for Success.

Macatangay, L. (2013). Tracer Study of BSCS Graduates of Lyceum of the Philippines University form 2004- 2009. Academic Research International, 4 (5): 361- 377. http://research.lpubatangas.edu.ph/wp-content/uploads/2014/05/ARInt-TRACERSTUDY-OF-BSCS-GRADUATES-OF-LPU.pdf

Mahfoodh, H. \& Hashim, S. (2021). Integrating Employability Skills in EFL Speaking and Writing Curricula through Digital Platforms. TESOL International Journal: 66-87.

Mahmood, K. (2012). LIS Curriculum Review Using Focus Group Interviews of Employers. Library Philosophy and Practice.

Malik, M. K. A. (2021). ELT Assessment Patterns Dictate Teaching-Learning Approaches: A Hindrance to Map out Employability and Life Skills. The Asian ESP Journal, 128.

Meñez, N. L. (2014). Tracer study of the Masters in Business Administration (MBA) graduates from 2008-2012. Asia Pacific Journal of Education, Arts and Sciences, 1(1), 14-18. http://oaji.net/articles/2015/1710-1440015465.pdf

Millington, C. (2001). The Use of Tracer Study for Enhancing Relevance and Marketability in Online and Distance Education. 
Mugwisi, T., \& Hikwa, L. (2015). A Tracer Study of Master of Science in Library and Information Science Graduates from the National University of Science and Technology, Bulawayo, Zimbabwe. African Journal of Library, Archives \& Information Science, 25(2).

Ocholla, D. N. \& Shongwe, M. (2011). A tracer study of LIS graduates at the University of Zululand, 2000-2009. Mousaion, 29(2),

227-245. http://www.lis.uzulu.ac.za/2011/Mzwandile\%20and\%200cholla\%20PROLISSA\%20p aper\%20revised\%20March\%2029.pdf

Ojedokun, A. A., \& Moahi, K. H. (2005). The Emerging Market for Information Professionals in Botswana and the Skills Requirements. Education for Information, 23: 129- 139.

Orence, A., \& Laguador, J. M. (2013). Employability of Maritime Graduates of Lyceum of the Philippines University from 2007-2011. International Journal of Research in Social Sciences, 3(3), 142.

Ramirez, T. L., Cruz, L. T., \& Alcantara, N. V. (2014). Tracer study of RTU graduates: an analysis. Researchers World, 5(1),

66. https://www.scinapse.io/papers/292833989\#fullText

Shuttleworth, M. (2008). Descriptive Research Design- Observing a Phenomenon. http://explorable.com/descriptive-research-design

Yusoff, Y. M., Omar, M. Z., Zaharim, A., Mohamed, A., \& Muhamad, N. (2012). Employability skills performance score for fresh engineering graduates in Malaysian industry. Asian Social Science, 8(16), 140. https://doi.org/10.5539/ass.v8n16p140

Zainab, A. N., Edzan, N. N., \& Rahman, S. S. A. (2004). Tracing Graduates to Ascertain Curriculum Relevance. Malaysian Journal of Library and Information Science, 9 (1) 27- 37. https://core.ac.uk/download/pdf/162015082.pdf

\section{$\underline{\text { AUTHORS'BIO }}$}

Jhordan Tino Cuilan, PhD, Associate Professor I, is a faculty member of the Department of Humanities and, to research writing, the Director of the Benguet State UniversityInternational Language Center. He obtained his Doctor of Philosophy Degree in Language Education in the same institution where he is affiliated.

Cynthia Tinoy-an Lubiton, PhD, Associate Professor II, is a faculty member and former Chairperson of the CAS-Department of Humanities, Benguet State University. She earned her MAT in English Language Arts at the Philippine Normal University (PNU-Manila) and her Doctor of Philosophy Degree in Language Education at the University of the Cordilleras. 